\title{
Epidemiological determinants and PCR results in Central African inhabitants with a new and frequent HTLV indeterminate Western Blot pattern exhibiting mostly p28, p32, p36, and a shifted GD21
}

Claudia Filippone ${ }^{1 *}$, Sylviane Bassot ${ }^{1}$, Edouard Betsem ${ }^{1,2}$, Sabine Plancoulaine ${ }^{1,3}$, Sara Calattini ${ }^{1}$, Antoine Gessain ${ }^{1}$

From 15th International Conference on Human Retroviruses: HTLV and Related Viruses

Leuven and Gembloux, Belgium. 5-8 June 2011

\section{Background}

HTLV indeterminate WB patterns are frequently observed in plasma/serum samples from persons living in intertropical areas.

\section{Material and methods}

In the framework of ongoing projets on HTLV-1/2 and related viruses in central Africa, we systematically analysed by WB, plasma from villagers living in south Cameroun. The studied group included 2155 individuals (mean age 44, range 2-90, 982 women/1173 men), either Bantous (1258) or Pygmies (897). All plasma samples were tested by WB (HTLV 2-4 MPD) with interpretation done according to manufacturer instructions. Only clear bands were considered as positive/informative. DNA extracted from buffy-coat were subjected to PCR using several primer pairs known to detect HTLV-1/2/ 3/4. Positive PCR bands were sequenced.

\section{Results}

Among the 2155 plasma samples, 48 were HTLV-1, 20 HTLV-2, and 134 HTLV. Furthermore, 955 were indeterminate including 100 HGIP (HTLV-I Gag-indeterminate pattern) [1], and 57 with a peculiar pattern exhibiting mostly p28, p32, p36, and a shifted GD21. The other samples were either WB negative (998) or

\footnotetext{
* Correspondence: claudia.filippone@pasteur.fr

'Unité d'Epidémiologie et Physiopathologie des Virus Oncogènes, URA CNRS 3015, Département de Virologie, Institut Pasteur, Paris, 75724 Cedex 15, France

Full list of author information is available at the end of the article
}

exhibited mostly faint or unique p19 or p24 bands. Most HTLV-1 samples and some HTLV were found PCR positive. In contrast, all the others (HTLV-2, HGIP, new WB pattern and other indeterminate) were found PCR negative except in one case of a HTLV-3 infection [2]. Epidemiological determinants of the persons with this new pattern were different from those with HTLV-1.

\section{Conclusions}

Search for the origin of this frequent new WB is ongoing with special insights concerning cross-reactivities with parasitic antigens as suggested for the HGIP pattern [3].

\section{Author details}

'Unité d'Epidémiologie et Physiopathologie des Virus Oncogènes, URA CNRS 3015, Département de Virologie, Institut Pasteur, Paris, 75724 Cedex 15, France. ${ }^{2}$ Faculté de Médecine et des Sciences Biomédicales, Université de Yaoundé I, Yaoundé, Cameroun. ${ }^{3}$ INSERM/Université Paris 5, Unité 550, Faculté de Médecine Necker, Paris, 75015, France.

Published: 6 June 2011

\section{References}

1. Mauclère $P$, Le Hesran JY, Mahieux R, Salla R, Mfoupouendoun J, Abada ET, Millan J, de Thé G, Gessain A: Demographic, ethnic, and geographical differences between human T cell lymphotropic virus (HTLV) type Iseropositive carriers and persons with HTLV-I Gag-indeterminate Western blots in Central Africa. J Infect Dis 1997, 176(2):505-509.

2. Calattini S, Betsem E, Bassot S, Chevalier SA, Mahieux R, Froment A, Gessain A: New strain of human T lymphotropic virus (HTLV) type 3 in a Pygmy from Cameroon with peculiar HTLV serologic results. $J$ Infect Dis 2009, 199(4):561-564 
3. Mahieux R, Horal P, Mauclère P, Mercereau-Puijalon O, Guillotte M,

Meertens L, Murphy E, Gessain A: Human T-cell lymphotropic virus type 1 gag indeterminate western blot patterns in Central Africa: relationship to Plasmodium falciparum infection. J Clin Microbiol 2000, 38(11):4049-4057.

doi:10.1186/1742-4690-8-S1-A73

Cite this article as: Filippone et al.: Epidemiological determinants and PCR results in Central African inhabitants with a new and frequent HTLV indeterminate Western Blot pattern exhibiting mostly p28, p32, p36, and a shifted GD21. Retrovirology 2011 8(Suppl 1):A73.

Submit your next manuscript to BioMed Central and take full advantage of:

- Convenient online submission

- Thorough peer review

- No space constraints or color figure charges

- Immediate publication on acceptance

- Inclusion in PubMed, CAS, Scopus and Google Scholar

- Research which is freely available for redistribution

Submit your manuscript at www.biomedcentral.com/submit
C Biomed Central 